\title{
Highly Regio- and Stereoselective Hydrogermylation of Fluorinated Alkyl Propiolate
}

\author{
Ranin. Kawtharania,b \\ Mirvat Elmasrib \\ Khalil Cherryc \\ Johan Jacquemin ${ }^{a}$ \\ Mohamed Abarbri*a \\ a Laboratoire de Physico-Chimie des Matériaux et des Electro- \\ lytes pour l'Energie (PCM2E). EA 6299, Avenue Monge Faculté \\ des Sciences, Parc de Grandmont, 37200 Tours, France \\ mohamed.abarbri@univ-tours.fr \\ b Laboratoire de Chimie Médicinale et de Produit naturels, Uni- \\ versité Libanaise, Faculté des Sciences I, Hadat, Lebanon \\ 'Laboratoire Matériaux, Catalyse, Environnement et Méthodes \\ Analytiques (MCEMA), Campus Universitaire de Hadat, Univer- \\ sité Libanaise, Lebanon
}

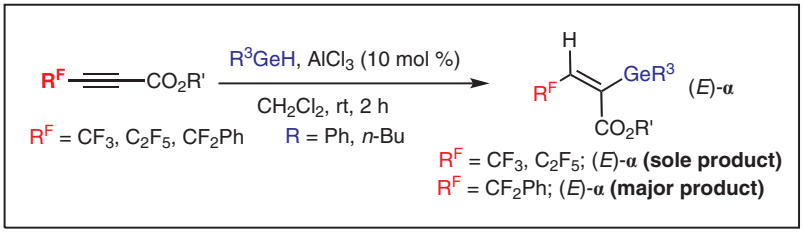

There are a few synthetic strategies that enable such an Received: 03.12.2018 Accepted: 04.01.2019 Published online: 28.01 .2019 DOI: 10.1055/s-0037-1611666; Art ID: so-2018-d0061-op License terms: cc)

Abstract The selective introduction of fluoroalkylated vinylmetals in controlled strategies is a challenging process for many chemists. This study reports the highly regio- and stereoselective synthesis of functionalized vinylgermanes bearing a perfluoroalkyl group from perfluoroalkylated acetylenic esters via $\mathrm{AlCl}_{3}$-catalyzed hydrogermylation. Regio- and stereoselectivity are highly dependent on the nature of the catalyst and the nature of the fluoroalkyl group of alkyne.

Key words regio- and stereoselective hydrogermylation, fluorinated ethyl propiolate, $\mathrm{AlCl}_{3}$, triphenyl- and tributylgermanes, fluorinated vinylgermanes

The field of organofluorine chemistry plays an important role in various applications including agrochemicals, soft materials, and especially pharmaceuticals, for which they are widely used as anticancer, antiarrhythmic, antihypertensive agents, anti-inflammatory, antidepressant, and antibiotics. ${ }^{1-3}$ In fact, the unique properties of fluorine has an exceptional impact on the electronic, lipophilic, and steric parameters, and on the acidity or basicity of organofluorinated molecules. Accordingly, the incorporation of fluorine atoms and perfluoroalkyl groups into organic compounds can modify their physiochemical properties, improve their metabolic stability, and change their biological activities. ${ }^{4}$ Therefore, the introduction of fluorinated building blocks in controlled strategies is considered an interesting challenge for many researchers, particularly those studying fluoroalkylated vinyl metals. ${ }^{5,6}$ However, the selective introduction of $(E)$ and $(Z)$ fluoroalkylated alkenes in the structure of natural products is still daunting. operation including the direct $\mathrm{sp}^{2} \mathrm{C}-\mathrm{H}$ bond functionalization, ${ }^{7}$ and olefination reactions. ${ }^{8}$ However, these methods suffer from limitations and stereoselectivity issues. Provided that regio- and stereoselectivity of the hydrometallation could be controlled, an efficient approach that would afford a straightforward entry to the selective preparation of low toxic fluoro-polysubstituted alkenes would rely on the hydrogermylation/cross coupling sequences from alkynes bearing fluorinated moieties. Although, germanium is slightly more expensive than tin, it is closer to silicon in its organic chemistry. Furthermore, germanium has a higher thermal stability, ${ }^{9}$ and a lower toxicity than tin. ${ }^{10}$

The addition of organogermanes to alkynes is the best method for the direct synthesis of vinylgermanes. ${ }^{11,12}$ However, hydrogermylation of carbonyl functionalized fluorinated alkynes, which provides a new entry to a wide range of functional fluorinated compounds, is still under investigation. To our knowledge, no hydrogermylation reaction of fluorinated alkynes type $1 \mathbf{a}^{13}$ has been described in the open literature. It is worth mentioning that we recently reported the first highly regio- and stereoselective free-metal hydrostannylation of ethyl 4,4,4-trifluorobut-2-ynoate (1a) leading to the synthesis of $\alpha$ and $\beta$-tributylstannyl-4,4,4trifluorobut-2-enoates without any additives (Scheme 1). ${ }^{14}$

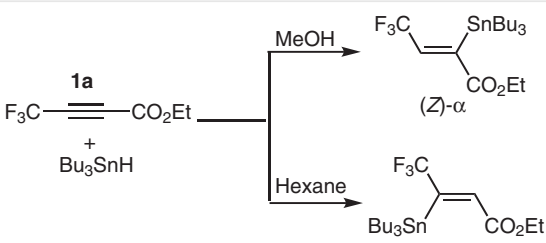

(Z) $-\beta$

Scheme 1 Previously described hydrostannylation of ethyl 4,4,4-trifluorobutenoate (1a) 
As a continuation of our previous study on the hydrometalation reaction of fluorinated alkynes for the preparation of new vinylmetals bearing a perfluoroalkyl group, ${ }^{14,15}$ we report herein, for the first time, a highly regio- and stereoselective hydrogermylation reaction of fluorinated alkynes of type $\mathbf{1}$ using the inexpensive Lewis acid $\mathrm{AlCl}_{3}$ as catalyst.

We first sought to determine the best conditions for a highly regio- and stereoselective hydrogermylation reaction of fluorinated ethyl propiolate 1a with $\mathrm{Ph}_{3} \mathrm{GeH}$ using different solvents and additives. The results are summarized in Table 1.

First, we examined the free-metal hydrogermylation of 1a using triphenylgermanium hydride in different solvents. Importantly, and contrary to what is generally observed in the case of hydrostannylation of alkyne $\mathbf{1 a},{ }^{14}$ the regioselectivity of this hydrogermylation reaction is relatively independent of the nature of the solvent (Table 1, entries 1-3). Thus, using hexane, methanol or dichloromethane as solvent, the hydrogermylation of alkyne $\mathbf{1 a}$ leads to the formation of the four possible isomers $(Z)-\mathbf{2} \boldsymbol{\alpha},(E)-\mathbf{2 \alpha},(Z)-\mathbf{2} \boldsymbol{\beta}$ and $(E)-2 \beta$. In all cases, the regioselectivity is greatly in favor of the $\beta$-regioisomer ( $>75 \%$ ). Although the ratio of formation of both $\alpha$ - and $\beta$-adducts is not exactly the same in each selected solvent, it is clear that the polarity of the solvents does not have a significant impact on the hydrogermylation reaction.

The regiochemistry of vinylgermanes was then deduced without ambiguity from NMR data, especially from the $J_{\mathrm{H}-\mathrm{F}}$ coupling patterns (Figure 1). Indeed, in the case of the $\alpha$ regioisomer, the coupling constant ${ }^{3} J_{\mathrm{H}-\mathrm{F}}$ reaches a value of ca. 7-8 Hz, whereas in the case of the $\beta$-regioisomer the coupling constant ${ }^{4} J_{\mathrm{H}-\mathrm{F}}$ is close to $1-2 \mathrm{~Hz}$. These values are consistent with previously published work. ${ }^{16}$
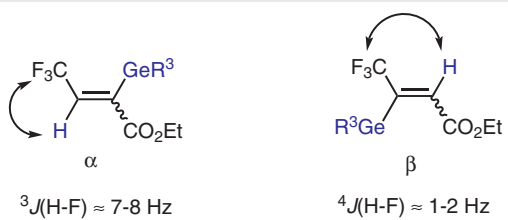

Figure $13 / \mathrm{H}-\mathrm{F}$ and $4 / \mathrm{H}-\mathrm{F}$ coupling constants of the two regioisomers $\alpha$ and $\beta$, respectively

For further investigations, the hydrogermylation of alkyne 1a was carried out under similar conditions in the presence of 2,2,6,6-tetramethylpiperidine-1-oxyl (TEMPO) as a radical scavenger (Table 1 , entry 4 ). Remarkably, the $\beta$ regioisomer was not formed and only the $\alpha$-isomer was isolated in $21 \%$ yield as a $64: 36$ mixture of the geometric isomers $(E)-\mathbf{2} \boldsymbol{\alpha}$ and $(Z)-\mathbf{2} \boldsymbol{\alpha}$, respectively. These results suggest that the reaction mechanism leading to the formation of the $\beta$-regioisomer takes place according to a radical process, while the $\alpha$-isomer could be the product of an ionic pathway. Furthermore, these results indicate that the free-metal hydrogermylation reaction proceeds mainly by a free radical mechanism. Organogermanium hydrides have been used for the radical and transition-metal-catalyzed hydrogermylation of alkynes since the mid-1950s, but such transformations still suffer from serious limitations such as low regio- and stereoselectivities. ${ }^{17-19}$ However, Blanchard et al. developed two efficient stereocomplementary routes for nonfunctionalized $(Z)$ - and $(E)$ - $\alpha$-trifluoromethylvinylgermanes by regio- and stereoselective hydrogermylation of $\alpha$-trifluoromethylated alkynes under transition-metalcatalyzed conditions or in presence of a radical initiator. ${ }^{20}$ Inspired by these results, fluorinated alkyne 1a was treated in dichloromethane with 1 equivalent of $\mathrm{Ph}_{3} \mathrm{GeH}$ in the presence of a catalytic amount of $\mathrm{Pd}\left(\mathrm{PPh}_{3}\right)_{4}(5 \mathrm{~mol} \%)$. The ${ }^{1} \mathrm{H}$ and ${ }^{19} \mathrm{~F}$ NMR spectra of the crude hydrogermylation product reveal a 60:40 mixture of the $\alpha$ and $\beta$ regioisomers was formed, respectively (entry 5$)$. The (E)-2 $\boldsymbol{\alpha}$ adduct, resulting from a cis-addition, constitutes the major product.

To explore more synthetic routes to perform the highly regio- and stereoselective hydrogermylation of alkyne 1a, we next directed our attention to the radical hydrogermylation of alkyne 1a. The treatment of alkyne $1 \mathbf{a}$ with $\mathrm{Ph}_{3} \mathrm{GeH}$ at room temperature using ammonium persulfate, ${ }^{21}$ as radical initiator in aqueous acetonitrile, provides a mixture of the $\alpha$ - and $\beta$-regioisomers in a ratio of about $22: 78$, with a majority of the trans-addition product $(Z)-\mathbf{2} \boldsymbol{\beta}$ (Table 1 , entry 6). Similar results were obtained but with a lower yield when we used the known radical initiator triethylborane $\mathrm{BEt}_{3}{ }^{22}$ (entries 7 ). Another class of catalyzed hydrogermylation reaction of functionalized alkynes was reported in 2005 based on the use of an expensive Lewis acid such as $\mathrm{B}\left(\mathrm{C}_{6} \mathrm{~F}_{5}\right)_{3}{ }^{23}$ Gevorgyan et al. demonstrated that the stereochemistry of this hydrogermylation reaction depends on the nature of the alkyne used; the reaction proceeded via a trans-addition pathway with simple alkynes and cis-addition with ethyl propiolate. Applying the same conditions as Gevorgyan et al., by using $\mathrm{BPh}_{3}$, a less expensive Lewis acid than $\mathrm{B}\left(\mathrm{C}_{6} \mathrm{~F}_{5}\right)_{3}$, the hydrogermylation of alkyne $1 \mathbf{a}$ with $\mathrm{Ph}_{3} \mathrm{GeH}$ proceeds mainly by trans-addition, yielding the major product $(Z)-\mathbf{2} \boldsymbol{\beta}$ with a small amount of the $\alpha$-adduct (entry 8).

Lewis acid $\mathrm{AlCl}_{3}$ mediated hydrosilylation and hydrostannylation of alkynes have been reported, ${ }^{24}$ but $\mathrm{AlCl}_{3}$ has never been used in the case of the hydrogermylation of alkynes. We therefore decided to perform the hydrogermylation reaction of alkyne $\mathbf{1 a}$ at room temperature in the presence of a catalytic amount of $\mathrm{AlCl}_{3}(10 \mathrm{~mol} \%)$ in toluene during 2 h. Remarkably, complete $\alpha$-regioselectivity of the hydrogermylation of alkyne 1a was observed, yielding $\alpha$ triphenylgermylacrylate $\mathbf{2} \alpha$ as the sole regioisomer in $74 \%$ yield (Table 1, entry 9). Furthermore, the stereoselectivity was also greatly in favor of the $(E)$-isomer ( $E>93 \%)$. Surprisingly, complete regio- and stereoselectivity of the hydrogermylation reaction was observed in the presence of 
Table 1 Hydrogermylation Reaction Conditions for 1a

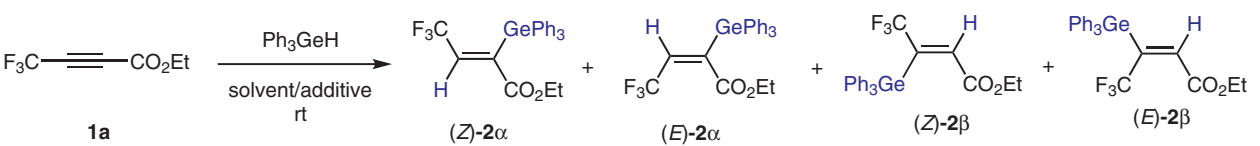

\begin{tabular}{|c|c|c|c|c|c|c|c|c|}
\hline Entry & Solvent & Additive (\%) & $\alpha / \beta$ & $(Z)-2 \alpha(\%)$ & $(E)-\mathbf{2} \alpha(\%)$ & $(Z)-\mathbf{2 \beta}(\%)$ & $(E)-\mathbf{2} \boldsymbol{\beta}(\%)$ & Yield (\%) \\
\hline 1 & methanol & - & $24: 76$ & 14.0 & 9.8 & 68.9 & 6.3 & $39^{a}$ \\
\hline 2 & hexane & - & $24: 76$ & 13.2 & 10.4 & 68.3 & 7.8 & $35^{\mathrm{a}}$ \\
\hline 3 & $\mathrm{CH}_{2} \mathrm{Cl}_{2}$ & - & $20: 80$ & 14.8 & 5.5 & 78.1 & 1.6 & $65^{\mathrm{a}}$ \\
\hline 4 & $\mathrm{CH}_{2} \mathrm{Cl}_{2}$ & TEMPO & $100: 0$ & 36.0 & 64.0 & 0.0 & 0.0 & $21^{b}$ \\
\hline 5 & $\mathrm{CH}_{2} \mathrm{Cl}_{2}$ & $\mathrm{Pd}\left(\mathrm{PPh}_{3}\right)_{4}(5)$ & $60: 40$ & 0.7 & 59.5 & 29.7 & 10.1 & $31^{\mathrm{a}}$ \\
\hline 6 & $\mathrm{CH}_{3} \mathrm{CN} / \mathrm{H}_{2} \mathrm{O}$ & $\left(\mathrm{NH}_{4}\right)_{2} \mathrm{~S}_{2} \mathrm{O}_{8}(20)$ & $22: 78$ & 18.4 & 3.9 & 76.9 & 0.8 & $83^{a}$ \\
\hline 7 & $\mathrm{CH}_{2} \mathrm{Cl}_{2}$ & $\mathrm{Et}_{3} \mathrm{~B}(10)$ & $32: 68$ & 25.6 & 7.0 & 63.5 & 4.1 & $50^{\mathrm{a}}$ \\
\hline 8 & $\mathrm{CH}_{2} \mathrm{Cl}_{2}$ & $\mathrm{BPh}_{3}(10)$ & $26: 74$ & 17.0 & 9.0 & 74.0 & 0.0 & $77^{\mathrm{a}}$ \\
\hline 9 & toluene & $\mathrm{AlCl}_{3}(10)$ & 100:0 & 6.6 & 93.4 & 0.0 & 0.0 & $74^{\mathrm{b}}$ \\
\hline 10 & $\mathrm{CH}_{2} \mathrm{Cl}_{2}$ & $\mathrm{AlCl}_{3}(10)$ & 100:0 & 0.0 & 100.0 & 0.0 & 0.0 & $92^{\mathrm{b}}$ \\
\hline
\end{tabular}

a Evaluated by ${ }^{1} \mathrm{H}$ NMR and ${ }^{19} \mathrm{~F}$ NMR.

${ }^{b}$ Yield of isolated product.

a catalytic amount of $\mathrm{AlCl}_{3}(10 \mathrm{~mol} \%)$ using $\mathrm{CH}_{2} \mathrm{Cl}_{2}$ as solvent, yielding $(E)-\mathbf{2} \boldsymbol{\alpha}$ as the sole product with excellent yield (entry 10).

In view of these results, we deduced that the optimum conditions for the hydrogermylation reaction of alkyne 1a to produce the corresponding trans-vinylgermane $(E)-\mathbf{2} \boldsymbol{\alpha}$ in a complete regio- and cis-stereoselective manner is $1 \mathrm{~mol}$ of $\mathrm{Ph}_{3} \mathrm{GeH}$ and $10 \mathrm{~mol} \%$ of $\mathrm{AlCl}_{3}$ in $\mathrm{CH}_{2} \mathrm{Cl}_{2}$ at room temperature for $2 \mathrm{~h}$.

The $E$ - and Z-configurations of the two regioisomers $\mathbf{2 \alpha}$ and $2 \boldsymbol{\beta}$ were assigned based on the values of the coupling constant $\left[{ }^{3} J(C(2)-F)\right]$; for which ${ }^{3} J[C(2)-F]$ of the $(Z)$-isomer is higher than that of the $(E)$-isomer (Figure 2). ${ }^{16,20}$

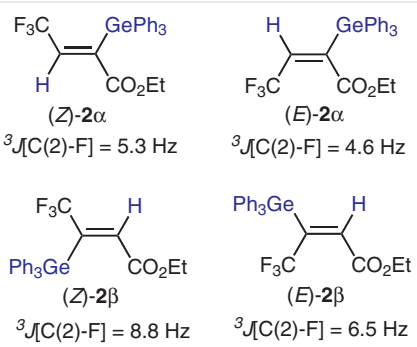

Figure $2 \mathrm{E}$ - and Z-configuration assignments of the two regioisomers $\alpha$ and $\beta$

To investigate the scope and limitations of the $\mathrm{AlCl}_{3}$ catalyzed hydrogermylation reaction, we next tested the hydrogermylation reaction of alkyne $\mathbf{1 a}$ using a less hindered organogermane compound such as $\mathrm{Bu}_{3} \mathrm{GeH}$. Remarkably, complete $\alpha$-regioselectivity of the hydrogermylation of alkyne 1a was observed. However, the reaction was found to be highly but not completely stereoselective, be- cause traces of the $Z$-stereoisomer were observed $(E / Z=$ $91: 9)$. Therefore, it seems that the size of the $R$ group on $\mathrm{R}_{3} \mathrm{GeH}$ is at the origin of this result. To further investigate the regiochemistry of vinylgermane $\mathbf{3}$, we then tested the radical hydrogermylation of alkyne $\mathbf{1 a}$ using $\mathrm{Bu}_{3} \mathrm{GeH}$ in the presence of $\mathrm{Et}_{3} \mathrm{~B}$ as a radical initiator and $\mathrm{CH}_{2} \mathrm{Cl}_{2}$ as solvent, providing a mixture of the four possible isomers $(Z)-3 \alpha,(E)$ $3 \boldsymbol{\alpha},(Z)-\mathbf{3} \boldsymbol{\beta}$ and $(E)-\mathbf{3} \boldsymbol{\beta}$ with the majority being the trans-addition product $(Z)-3 \boldsymbol{\beta}$ (Scheme 2 ).

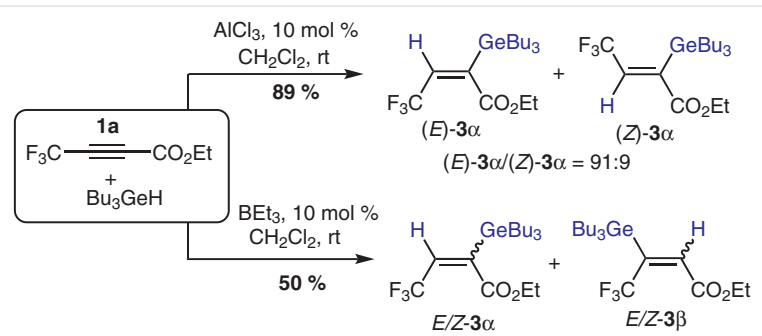

$(E)-3 \alpha /(Z)-3 \alpha /(E)-3 \beta /(Z)-3 \beta=8: 15: 9: 68$

Scheme 2 Hydrogermylation reactions of $1 \mathbf{a}$ using $\mathrm{Bu}_{3} \mathrm{GeH}$

Another fluorinated $\alpha, \beta$-acetylenic ester, ethyl 4,4,5,5,5pentafluoropent-2-ynoate (1) $),{ }^{13}$ was then treated under the same conditions as those described above. The results obtained were very similar to those obtained in the case of alkyne 1a. The hydrogermylation of alkyne $\mathbf{1 b}$ using $\mathrm{AlCl}_{3}$ as catalyst in $\mathrm{CH}_{2} \mathrm{Cl}_{2}$ and $\mathrm{Ph}_{3} \mathrm{GeH}$ yields exclusively the cisaddition product $(E)-\mathbf{4} \boldsymbol{\alpha}$ in $91 \%$ yield. Likewise, as observed in the case of alkyne 1a, there was a slight loss of stereoselectivity when triphenylgermane was substituted with the less bulky tributylgermane, but the regioselectivity remained complete. Similarly, radical hydrogermylation of 
alkyne 1b using $\mathrm{Bu}_{3} \mathrm{GeH}$ or $\mathrm{Ph}_{3} \mathrm{GeH}$ in the presence of $\mathrm{Et}_{3} \mathrm{~B}$ was performed, yielding a mixture of $\alpha$ - and $\beta$-regioisomers in a ratio of ca. 33:67, respectively, with the majority of the trans-addition product $(Z)-\mathbf{4 \beta}$ and $(Z)-\mathbf{5 \beta}$ (Scheme 3 ).

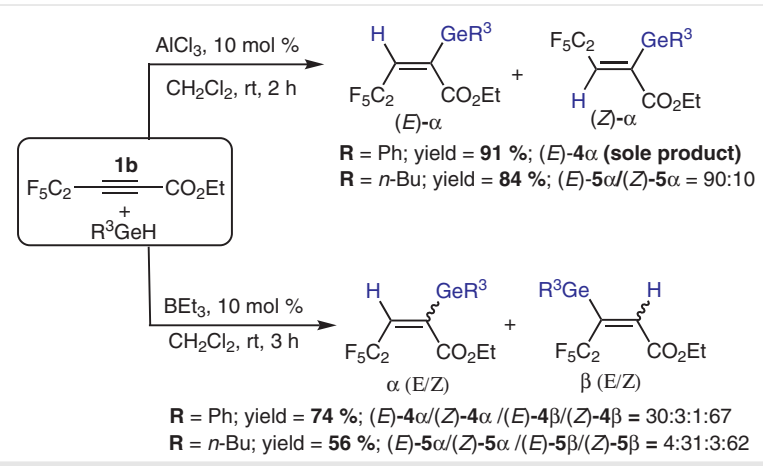

Scheme 3 Hydrogermylation of $\mathbf{1} \mathbf{b}$ using $\mathrm{Ph}_{3} \mathrm{GeH}$ and $\mathrm{Bu}_{3} \mathrm{GeH}$

To better understand the role of the fluorinated group of the alkyne in the orientation of the regioselectivity of the $\mathrm{AlCl}_{3}$-catalyzed hydrogermylation reaction, hydrogermylation of methyl 4,4-difluoro-4-phenylbut-2-ynoate (1c) ${ }^{25}$ using $\mathrm{Ph}_{3} \mathrm{GeH}$ was performed under the conditions described above (Scheme 4). Although the reaction gave the $(E)-\mathbf{6} \boldsymbol{\alpha}$ adduct as the major isomer, it was accompanied by the formation of the other three isomers in the propor-

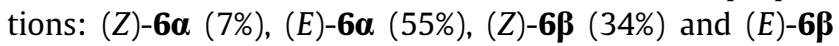
(4\%).

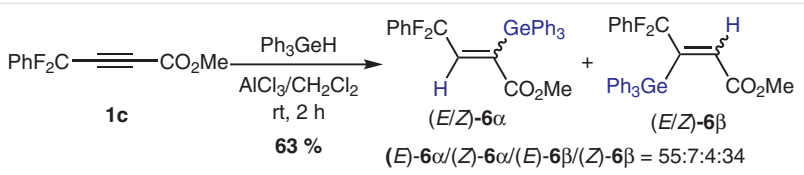

Scheme $4 \mathrm{AlCl}_{3}$-catalyzed hydrogermylation of $1 \mathrm{c}$ using $\mathrm{Ph}_{3} \mathrm{GeH}$

It is worth mentioning that the regio- and stereochemistry for the vinylgermanes $3,4,5$ and 6 were deduced from the ${ }^{3} J_{\mathrm{H}-\mathrm{F}}, J_{\mathrm{H}-\mathrm{F}}$ and ${ }^{3} J_{\mathrm{C}-\mathrm{F}}$ coupling patterns by following the analyses described above in case of vinylgermane 2 .

Despite the limited number of fluorinated alkynes used, it seems that the regioselectivity of this hydrogermylation reaction is also very dependent on the nature of the fluorinated group of the alkyne. This dependence may be related to the difference of the partial charges on sp-carbon atoms of the alkyne. To investigate this in greater detail, ab initio calculations were carried out (full minimization of the structure realized using the $\mathrm{HF} / 6-311 \mathrm{G}^{*}$ level of theory followed by a single-point calculation with the basic set DFT/B3-LYP/def-TZVP within Turbomole 7.2) to determine the partial charge of these two sp-carbon atoms (Scheme 5), thanks to the Natural Population Analysis approach. ${ }^{26} \mathrm{~A}$ larger difference on the partial charges $\left(\Delta=\delta C_{3}-\delta C_{2}\right)$ was observed in the cases of alkynes $\mathbf{1 a}$ and $\mathbf{1 b}$ than in alkyne 1c (Figure 3). Furthermore, changing a $-\mathrm{CF}_{3}\left(\right.$ or $\left.-\mathrm{C}_{2} \mathrm{~F}_{5}\right)$ group with a $\mathrm{PhF}_{2} \mathrm{C}$ induces a significant charge inversion on spcarbon atoms. To further understand the origin of the regioselectivity of this hydrogermylation reaction by using $\mathrm{AlCl}_{3}$ as catalyst, a similar charge analysis was carried out on intermediates (1'a', $\mathbf{1} \mathbf{b}^{\prime}$ and $\left.\mathbf{1} \mathbf{c}^{\prime}\right)$. By looking at the partial charge of each carbocation, it seems that $\mathrm{C} 3$ of $\mathbf{1} \mathbf{c}^{\prime}$ is less electrophile than those of $\mathbf{1} \mathbf{a}^{\prime}$ and $\mathbf{1} \mathbf{b}^{\prime}$. This may explain the higher regioselectivity observed in the case of alkynes $\mathbf{1 a}$ and $\mathbf{1 b}$ (Figure 3).
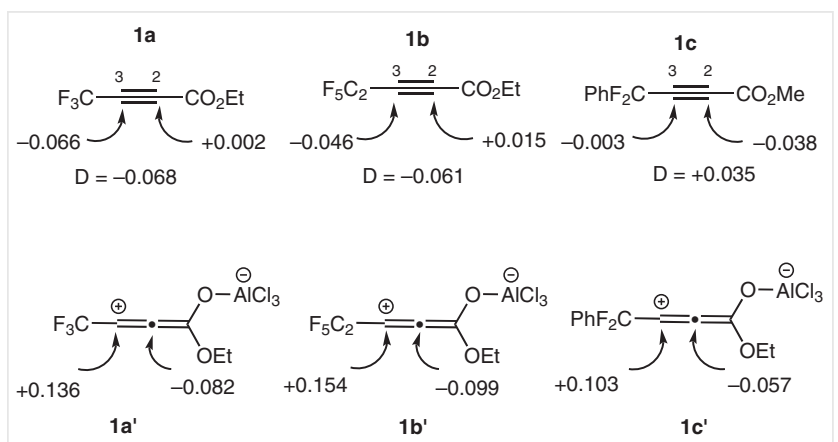

Figure 3 Partial charges on the sp-carbon atoms

By taking into consideration the charge distribution of these two sp-carbon atoms, a plausible ionic mechanism for the $\mathrm{AlCl}_{3}$-catalyzed cis hydrogermylation of fluorinated alkynes type $\mathbf{1}$ is shown in Scheme 5. The coordination of the ester-carbonyl group of alkynes of type $\mathbf{1}$ to $\mathrm{AlCl}_{3}$ produces the zwitterionic intermediate $\mathbf{I}$, which is transformed into allenoate II through hydride transfer from $\mathrm{Ph}_{3} \mathrm{GeH}$ to the cationic center of I. Trapping of intermediate II with germylium-type species occurs from the less hindered face, cis to $\mathrm{H}$, thus providing the cis-hydrogermylation $(E)-\alpha$ products and regenerating the $\mathrm{AlCl}_{3}$ catalyst.

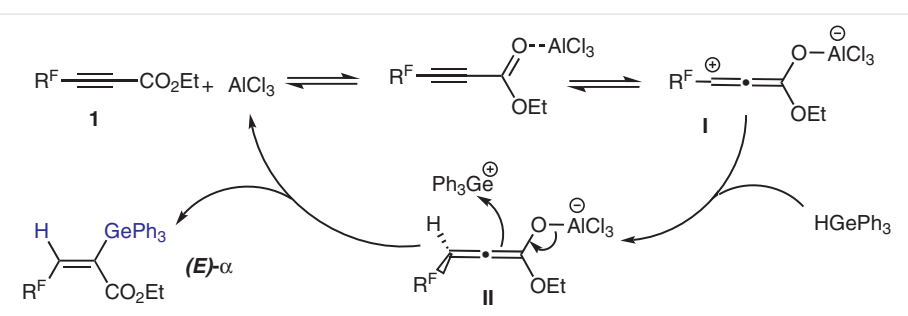

Scheme 5 Plausible Mechanism for cis-hydrogermylation of fluorinated alkynes 1 
In summary, the $\mathrm{AlCl}_{3}$-catalyzed hydrogermylation reaction of ethyl propiolate bearing a perfluoroalkyl group can be achieved under very mild conditions. This reaction proceeds in a highly regio- and stereocontrolled manner, providing functionalized vinylgermane products with excellent yields. Studies are now under way to delineate the synthetic utility of these reagents and the results of these investigations will be reported in due course.

Most reagents were obtained from commercial sources and used as received. All reactions were carried out under inert atmosphere. Petroleum ether (PE) used had a boiling range $40-60{ }^{\circ} \mathrm{C}, \mathrm{CH}_{2} \mathrm{Cl}_{2}$ was distilled from calcium hydride and stored under Argon. Thin-layer chromatography (TLC) was performed on Merck 60F254 plates. Column chromatography was carried out with Merck silica gel 60 (0.040-0.063 mm, 230-400 mesh). All ${ }^{1} \mathrm{H},{ }^{13} \mathrm{C}$, and ${ }^{19} \mathrm{~F}$ NMR spectra were recorded with a $300 \mathrm{MHz}$ Bruker Avance FT NMR spectrometer (300 MHz, 75 or $282 \mathrm{MHz}$, respectively). All chemical shifts are given as $\delta$ values (ppm) with reference to tetramethylsilane (TMS) as an internal standard. The peak patterns are indicated as follows: s, singlet; $\mathrm{d}$, doublet; t, triplet; q, quartet; $\mathrm{m}$, multiplet. The coupling constants J are reported in Hertz $(\mathrm{Hz})$. Electrospray ionization high-resolution mass spectrometry experiments (HRMS) were performed with a hybrid tandem quadrupole/time-of flight (Q-TOF) instrument, equipped with a pneumatically assisted electrospray (Z-spray) ion source (Micromass, Manchester, U.K.) operated in positive mode.

$\mathrm{AlCl}_{3}$-Catalyzed Hydrogermylation Reaction: Synthesis of $(E)-\alpha$ Adduct; General Procedure A

Alkyne 1a (143 mg, $0.86 \mathrm{mmol}$ ) was placed in a vial containing a magnetic stirring bar. $\mathrm{AlCl}_{3}\left(12 \mathrm{mg}, 0.09 \mathrm{mmol}, 10 \mathrm{~mol} \%\right.$ in $\mathrm{CH}_{2} \mathrm{Cl}_{2}(0.5$ $\mathrm{mL}$ ) was added to the vial. The vial was sealed with a Teflon-coated silicon rubber septum, evacuated and filled with argon. The reaction mixture was set at $0{ }^{\circ} \mathrm{C}$. After $5 \mathrm{~min}$ stirring, $\mathrm{Ph}_{3} \mathrm{GeH}(220 \mathrm{mg}, 0.72$ mmol) was then added. The mixture was stirred for 1 hour at $0{ }^{\circ} \mathrm{C}$, then $\mathrm{Et}_{3} \mathrm{~N}$ ( $37 \mathrm{mg}, 0.36 \mathrm{mmol}$ ) was added. The reaction mixture was allowed to warm to r.t. then hexane was added and the mixture was filtered through Celite. The solvent was evaporated under vacuum and column chromatography through silica gel afforded the purified (E)-2a-isomer (290 mg, 92\%) with complete regio- and stereoselectivity.

Radical Hydrogermylation using $\mathrm{BEt}_{3}$ : Synthesis of Mixture of Isomers $(E)-\beta,(Z)-\beta,(E)-\alpha,(Z)-\alpha$; General Procedure B

Triethylborane ( $6 \mathrm{mg}, 0.1$ equiv, $0.06 \mathrm{mmol}$ ), $\mathrm{Bu}_{3} \mathrm{GeH}$ (177 mg, 1.2 equiv, $0.72 \mathrm{mmol})$ and $\mathrm{CH}_{2} \mathrm{Cl}_{2}(0.4 \mathrm{~mL})$ were placed in a vial containing a magnetic stirring bar. The vial was sealed with a teflon-coated silicon rubber septum, evacuated and filled with argon. Alkyne 1a ( $100 \mathrm{mg}, 1$ equiv, $0.60 \mathrm{mmol}$ ) was added slowly to the reaction mixture. The reaction mixture was left for 3 hours under agitation at r.t. then the solvent was evaporated under vacuum. Column chromatography through silica gel using PE as eluent afforded the four isomers (247 $\mathrm{mg}, 50 \%$ overall yield).

$(E)-\mathbf{2} \boldsymbol{\alpha},(E)-\mathbf{3} \boldsymbol{\alpha},(E)-\mathbf{4} \boldsymbol{\alpha}$ and $(E)-\mathbf{5} \boldsymbol{\alpha}$ were characterized by ${ }^{1} \mathrm{H},{ }^{13} \mathrm{C}$, and ${ }^{19} \mathrm{~F}$ NMR and HRMS; whereas, all other products obtained in the form of a mixture of isomers were characterized at least by ${ }^{1} \mathrm{H}$ NMR and ${ }^{19} \mathrm{~F}$ NMR spectroscopy.

(E)-Ethyl 4,4,4-Trifluoro-2-(triphenylgermyl)but-2-enoate [(E)-2a] (E)-2 $\boldsymbol{\alpha}$ was obtained as the sole product by following general procedure A.
Yield: 92\%; white solid; $\mathrm{mp} 85-86{ }^{\circ} \mathrm{C}$.

${ }^{1} \mathrm{H}$ NMR $\left(300 \mathrm{MHz}, \mathrm{CDCl}_{3}\right): \delta=7.67-7.46(\mathrm{~m}, 15 \mathrm{H}), 5.88\left(\mathrm{q}, J_{\mathrm{H}-\mathrm{F}}=\right.$ $7.2 \mathrm{~Hz}, 1 \mathrm{H}), 4.07$ (q, J = 7.1 Hz, $2 \mathrm{H}), 1.02(\mathrm{t}, J=7.1 \mathrm{~Hz}, 3 \mathrm{H})$.

${ }^{13} \mathrm{C}$ NMR $\left(\mathrm{CDCl}_{3}, 75 \mathrm{MHz}\right): \delta=168.3,146.4\left(\mathrm{q}, J_{\mathrm{C}-\mathrm{F}}=4.7 \mathrm{~Hz}\right), 135.3$ (6C), 132.9 (3C), 130.1 (3C), 129.5 (q, $\left.J_{C-F}=35.2 \mathrm{~Hz}\right), 128.7(6 C), 121.3$ $\left(\mathrm{q}, J_{\mathrm{C}-\mathrm{F}}=272.5 \mathrm{~Hz}\right), 61.4,13.8$.

${ }^{19} \mathrm{~F} \mathrm{NMR}\left(\mathrm{CDCl}_{3}, 282 \mathrm{MHz}\right): \delta=-61.84$.

HRMS (ESI): $m / z[\mathrm{M}+\mathrm{H}]^{+}$calcd for $\mathrm{C}_{24} \mathrm{H}_{22} \mathrm{~F}_{3} \mathrm{GeO}_{2}$ : 473.02904; found: 473.02710

(E)-Ethyl 4,4,4-Trifluoro-3-(triphenylgermyl)but-2-enoate [(E)-2 $\beta]$

(E)-2 $\boldsymbol{\beta}$ was obtained as a mixture with the other three isomers by following general procedure $\mathrm{B}$.

${ }^{1} \mathrm{H} \mathrm{NMR}\left(\mathrm{CDCl}_{3}, 300 \mathrm{MHz}\right): \delta=7.66-7.34(\mathrm{~m}, 15 \mathrm{H}), 6.41$ (bs, $\left.1 \mathrm{H}\right)$, $4.24(\mathrm{q}, J=7.1 \mathrm{~Hz}, 2 \mathrm{H}), 1.30(\mathrm{t}, J=7.1 \mathrm{~Hz}, 3 \mathrm{H})$.

${ }^{19} \mathrm{~F} \mathrm{NMR}\left(\mathrm{CDCl}_{3}, 282 \mathrm{MHz}\right): \delta=-54.58$.

(Z)-Ethyl 4,4,4-Trifluoro-2-(triphenylgermyl)but-2-enoate [(Z)-2 $\alpha]$

$(Z)-\mathbf{\alpha} \alpha$ was obtained as a mixture with the other three isomers by following general procedure $\mathrm{B}$.

${ }^{1} \mathrm{H}$ NMR $\left(\mathrm{CDCl}_{3}, 300 \mathrm{MHz}\right): \delta=7.67-7.46(\mathrm{~m}, 15 \mathrm{H}), 6.99\left(\mathrm{q}, J_{\mathrm{H}-\mathrm{F}}=\right.$ $7.9 \mathrm{~Hz}, 1 \mathrm{H}), 3.72(\mathrm{q}, J=7.1 \mathrm{~Hz}, 2 \mathrm{H}), 0.87(\mathrm{t}, J=7.1 \mathrm{~Hz}, 3 \mathrm{H})$.

${ }^{13} \mathrm{C} \mathrm{NMR}\left(\mathrm{CDCl}_{3}, 75 \mathrm{MHz}\right): \delta=169.6,146.9\left(\mathrm{q}, J_{\mathrm{C}-\mathrm{F}}=5.3 \mathrm{~Hz}\right), 135.7$ (6C), $134.3\left(\mathrm{q}, J_{\mathrm{C}-\mathrm{F}}=35.8 \mathrm{~Hz}\right), 133.2(3 \mathrm{C}), 129.5(3 \mathrm{C}), 128.7(6 \mathrm{C}), 121.3$ $\left(\mathrm{q}, J_{\mathrm{C}-\mathrm{F}}=272.5 \mathrm{~Hz}\right), 61.4,13.8$.

${ }^{19} \mathrm{~F} \mathrm{NMR}\left(\mathrm{CDCl}_{3}, 282 \mathrm{MHz}\right): \delta=-60.5$.

(Z)-Ethyl 4,4,4-Trifluoro-3-(triphenylgermyl)but-2-enoate [(Z)-2 $\beta]$ (Z)-2 $\boldsymbol{\beta}$ was obtained as a mixture with the other three isomers by following general procedure $\mathrm{B}$.

${ }^{1} \mathrm{H}$ NMR $\left(\mathrm{CDCl}_{3}, 300 \mathrm{MHz}\right): \delta=7.66-7.34(\mathrm{~m}, 15 \mathrm{H}), 7.26\left(\mathrm{q}, J_{\mathrm{H}-\mathrm{F}}=\right.$ $2.2 \mathrm{~Hz}, 1 \mathrm{H}), 3.50(\mathrm{q}, J=7.1 \mathrm{~Hz}, 2 \mathrm{H}), 0.77(\mathrm{t}, J=7.1 \mathrm{~Hz}, 3 \mathrm{H})$.

${ }^{13} \mathrm{C} \mathrm{NMR}\left(\mathrm{CDCl}_{3}, 75 \mathrm{MHz}\right): \delta=164.5,144.6\left(\mathrm{q}, J_{\mathrm{C}-\mathrm{F}}=31.1 \mathrm{~Hz}\right), 137.8(\mathrm{q}$, $\left.J_{\mathrm{C}-\mathrm{F}}=8.8 \mathrm{~Hz}\right), 134.9(6 \mathrm{C}), 129.3(3 \mathrm{C}), 128.4(6 \mathrm{C}), 128.4(3 \mathrm{C}), 125.0(\mathrm{q}$, $\left.J_{\mathrm{C}-\mathrm{F}}=272.8 \mathrm{~Hz}\right), 61.3,13.4$.

${ }^{19} \mathrm{~F} \mathrm{NMR}\left(\mathrm{CDCl}_{3}, 282 \mathrm{MHz}\right): \delta=-60.7$.

(E)-Ethyl 4,4,4-Trifluoro-2-(tributylgermyl)but-2-enoate [(E)-3a]

$(E)-3 \boldsymbol{\alpha}$ was obtained as a mixture with $(Z)-\mathbf{3} \boldsymbol{\alpha}$ by following general procedure A.

Yield: 89\%; colorless oil.

${ }^{1} \mathrm{H} \mathrm{NMR}\left(\mathrm{CDCl}_{3}, 300 \mathrm{MHz}\right): \delta=5.71\left(\mathrm{q}, J_{\mathrm{H}-\mathrm{F}}=7.23 \mathrm{~Hz}, 1 \mathrm{H}\right), 4.22(\mathrm{q}, J=$ $7.1 \mathrm{~Hz}, 2 \mathrm{H}), 1.38-1.28(\mathrm{~m}, 18 \mathrm{H}), 0.95-0.87(\mathrm{~m}, 12 \mathrm{H})$.

${ }^{13} \mathrm{C} \mathrm{NMR}\left(\mathrm{CDCl}_{3}, 75 \mathrm{MHz}\right): \delta=169.3,149.2\left(\mathrm{q}, J_{\mathrm{C}-\mathrm{F}}=4.6 \mathrm{~Hz}\right), 125.3(\mathrm{q}$, $\left.J_{\mathrm{C}-\mathrm{F}}=33.6 \mathrm{~Hz}\right), 121.4\left(\mathrm{q}, J_{\mathrm{C}-\mathrm{F}}=272.3 \mathrm{~Hz}\right), 68.1,26.8(3 \mathrm{C}), 26.4(3 \mathrm{C})$, 14.2, 13.7 (3C), $12.6(3 \mathrm{C})$.

${ }^{19} \mathrm{~F} \mathrm{NMR}\left(\mathrm{CDCl}_{3}, 282 \mathrm{MHz}\right): \delta=-61.93$.

HRMS (ESI): $m / z[\mathrm{M}+\mathrm{H}]^{+}$calcd for $\mathrm{C}_{18} \mathrm{H}_{34} \mathrm{~F}_{3} \mathrm{GeO}_{2}$ : 413.02930; found: 413.02721.

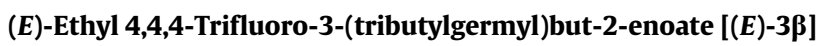

$(E)-3 \beta$ was obtained as a mixture with the other three isomers by following general procedure $\mathrm{B}$.

${ }^{1} \mathrm{H} \mathrm{NMR}\left(\mathrm{CDCl}_{3}, 300 \mathrm{MHz}\right): \delta=6.35\left(\mathrm{q}, J_{\mathrm{H}-\mathrm{F}}=1.7 \mathrm{~Hz}, 1 \mathrm{H}\right), 4.22(\mathrm{q}, J=$ $7.1 \mathrm{~Hz}, 2 \mathrm{H}), 1.38-1.28$ (m, $18 \mathrm{H}), 0.95-0.87(\mathrm{~m}, 12 \mathrm{H})$.

${ }^{19} \mathrm{~F}$ NMR $\left(\mathrm{CDCl}_{3}, 282 \mathrm{MHz}\right): \delta=-61.63$.

(Z)-Ethyl 4,4,4-Trifluoro-2-(tributylgermyl)but-2-enoate [(Z)-3 $\alpha]$ 
$(Z)-3 \boldsymbol{\alpha}$ was obtained as a mixture with $(\boldsymbol{E})-\mathbf{3} \boldsymbol{\alpha}$ by following general procedure $A$.

${ }^{1} \mathrm{H} \mathrm{NMR}\left(\mathrm{CDCl}_{3}, 300 \mathrm{MHz}\right): \delta=6.61\left(\mathrm{q}, J_{\mathrm{H}-\mathrm{F}}=8.5 \mathrm{~Hz}, 1 \mathrm{H}\right), 4.22(\mathrm{q}, J=$ $7.1 \mathrm{~Hz}, 2 \mathrm{H}), 1.38-1.28(\mathrm{~m}, 18 \mathrm{H}), 0.95-0.87(\mathrm{~m}, 12 \mathrm{H})$.

${ }^{13} \mathrm{C}$ NMR $\left(\mathrm{CDCl}_{3}, 75 \mathrm{MHz}\right): \delta=170.6,150.3\left(\mathrm{q}, J_{\mathrm{C}-\mathrm{F}}=5.5 \mathrm{~Hz}\right), 132.6(\mathrm{q}$, $\left.J_{\mathrm{C}-\mathrm{F}}=35.5 \mathrm{~Hz}\right), 122.9\left(\mathrm{q}, J_{\mathrm{C}-\mathrm{F}}=269.8 \mathrm{~Hz}\right), 61.5,27.1(3 \mathrm{C}), 25.7(3 \mathrm{C}), 14.2$ (3C), 14.0, 13.9 (3C).

${ }^{19} \mathrm{~F} \mathrm{NMR}\left(\mathrm{CDCl}_{3}, 282 \mathrm{MHz}\right): \delta=-60.50$.

(Z)-Ethyl 4,4,4-Trifluoro-3-(tributylgermyl)but-2-enoate [(Z)-3ß]

$(Z)-3 \beta$ was obtained as a mixture with the other three isomers by following general procedure $\mathrm{B}$.

${ }^{1} \mathrm{H} \mathrm{NMR}\left(\mathrm{CDCl}_{3}, 300 \mathrm{MHz}\right): \delta=6.89\left(\mathrm{q}, J_{\mathrm{H}-\mathrm{F}}=2.3 \mathrm{~Hz}, 1 \mathrm{H}\right), 4.23(\mathrm{q}, J=$ $7.1 \mathrm{~Hz}, 2 \mathrm{H}), 1.38-1.28(\mathrm{~m}, 18 \mathrm{H}), 0.95-0.87(\mathrm{~m}, 12 \mathrm{H})$.

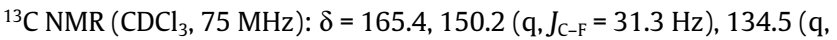
$\left.J_{\mathrm{C}-\mathrm{F}}=9.6 \mathrm{~Hz}\right), 125.6\left(\mathrm{q}, J_{\mathrm{C}-\mathrm{F}}=272.5 \mathrm{~Hz}\right), 61.1,27.1$ (3C), $26.3(3 \mathrm{C}), 14.1$, $13.6(3 \mathrm{C}), 13.4(3 \mathrm{C})$.

${ }^{19} \mathrm{~F} \mathrm{NMR}\left(\mathrm{CDCl}_{3}, 282 \mathrm{MHz}\right): \delta=-61.76$.

(E)-Ethyl 4,4,5,5,5-Pentafluoro-2-(triphenylgermyl)pent-2-enoate $[(E)-4 \alpha]$

(E)-4a was obtained as a sole product by following general procedure A.

Yield: $91 \%$; white solid; $\mathrm{mp} 85-86^{\circ} \mathrm{C}$.

${ }^{1} \mathrm{H} \mathrm{NMR}\left(\mathrm{CDCl}_{3}, 300 \mathrm{MHz}\right): \delta=7.54-7.39(\mathrm{~m}, 15 \mathrm{H}), 5.80\left(\mathrm{t}, J_{\mathrm{H}-\mathrm{F}}=\right.$ $13.3 \mathrm{~Hz}, 1 \mathrm{H}), 3.95(\mathrm{q}, J=7.1 \mathrm{~Hz}, 2 \mathrm{H}), 1.0(\mathrm{t}, J=7.1 \mathrm{~Hz}, 3 \mathrm{H})$.

${ }^{13} \mathrm{C} \mathrm{NMR}\left(\mathrm{CDCl}_{3}, 75 \mathrm{MHz}\right): \delta=168.3,145.2\left(\mathrm{t}, J_{\mathrm{C}-\mathrm{F}}=4.8 \mathrm{~Hz}\right), 135.6(6 \mathrm{C})$, 132.7 (3C), 130.1 (3), 128.7 (6C), 126.8 (t, $\left.J_{C-F}=23.4 \mathrm{~Hz}\right), 118.8$ (qt, $J_{C-F}$ $=284.7 \mathrm{~Hz}, 36.7 \mathrm{~Hz}), 111.6\left(\mathrm{tq}, J_{\mathrm{C}-\mathrm{F}}=252.8 \mathrm{~Hz}, 38.8 \mathrm{~Hz}\right), 61.3,13.8$.

${ }^{19} \mathrm{~F} \mathrm{NMR}\left(\mathrm{CDCl}_{3}, 282 \mathrm{MHz}\right): \delta=-84.55\left(\mathrm{t}, J_{\mathrm{F}-\mathrm{F}}=2.0 \mathrm{~Hz}, \mathrm{CF}_{3}\right),-113.96(\mathrm{q}$, $\left.J_{\mathrm{F}-\mathrm{F}}=2.0 \mathrm{~Hz}, \mathrm{CF}_{2}\right)$.

HRMS (ESI): $m / z$ [M $+\mathrm{H}]^{+}$calcd for $\mathrm{C}_{25} \mathrm{H}_{22} \mathrm{~F}_{5} \mathrm{GeO}_{2}$ : 523.07463 ; found: 523.07265.

(E)-Ethyl 4,4,5,5,5-Pentafluoro-3-(triphenylgermyl)pent-2-enoate $[(E)-4 \beta]$

(E)-4\$ was obtained as a mixture with the other three isomers by following general procedure $\mathrm{B}$.

${ }^{1} \mathrm{H}$ NMR $\left(\mathrm{CDCl}_{3}, 300 \mathrm{MHz}\right): \delta=7.66-7.3(\mathrm{~m}, 15 \mathrm{H}), 6.66\left(\mathrm{t}, J_{\mathrm{H}-\mathrm{F}}=\right.$ $1.7 \mathrm{~Hz}, 1 \mathrm{H}), 4.28(\mathrm{q}, J=7.1 \mathrm{~Hz}, 2 \mathrm{H}), 0.86(\mathrm{t}, J=7.1 \mathrm{~Hz}, 3 \mathrm{H})$.

${ }^{19} \mathrm{~F} \mathrm{NMR}\left(\mathrm{CDCl}_{3}, 282 \mathrm{MHz}\right): \delta=-81.61\left(\mathrm{t}, J_{\mathrm{F}-\mathrm{F}}=2.2 \mathrm{~Hz}, \mathrm{CF}_{3}\right),-102.14(\mathrm{q}$, $J_{\mathrm{F}-\mathrm{F}}=2.2 \mathrm{~Hz}, \mathrm{CF}_{2}$ ).

(Z)-Ethyl 4,4,5,5,5-Pentafluoro-2-(triphenylgermyl)pent-2-enoate [(Z)-4a]

(Z)-4a was obtained as a mixture with the other three isomers by following general procedure $\mathrm{B}$.

${ }^{1} \mathrm{H} \mathrm{NMR}\left(\mathrm{CDCl}_{3}, 300 \mathrm{MHz}\right): \delta=7.66-7.3(\mathrm{~m}, 15 \mathrm{H}), 5.89\left(\mathrm{t}, J_{\mathrm{H}-\mathrm{F}}=\right.$ $14.2 \mathrm{~Hz}, 1 \mathrm{H}), 4.03(\mathrm{q}, J=7.1 \mathrm{~Hz}, 2 \mathrm{H}), 1.06(\mathrm{t}, J=7.1 \mathrm{~Hz}, 3 \mathrm{H})$.

${ }^{19} \mathrm{~F} \mathrm{NMR}\left(\mathrm{CDCl}_{3}, 282 \mathrm{MHz}\right): \delta=-84.59\left(\mathrm{t}, J_{\mathrm{F}-\mathrm{F}}=2.2 \mathrm{~Hz}, \mathrm{CF}_{3}\right),-113.89(\mathrm{q}$, $\left.J_{\mathrm{F}-\mathrm{F}}=2.2 \mathrm{~Hz}, \mathrm{CF}_{2}\right)$.

(Z)-Ethyl 4,4,5,5,5-Pentafluoro-3-(triphenylgermyl)pent-2-enoate $[(Z)-4 \beta]$

(Z)-4及 was obtained as a mixture with the other three isomers by following general procedure $B$.

${ }^{1} \mathrm{H}$ NMR $\left(\mathrm{CDCl}_{3}, 300 \mathrm{MHz}\right): \delta=7.66-7.3(\mathrm{~m}, 15 \mathrm{H}), 7.32\left(\mathrm{t}, J_{\mathrm{H}-\mathrm{F}}=\right.$ $1.9 \mathrm{~Hz}, 1 \mathrm{H}), 3.48$ (q, $J=7.1 \mathrm{~Hz}, 2 \mathrm{H}), 1.01(\mathrm{t}, J=7.1 \mathrm{~Hz}, 3 \mathrm{H})$.

${ }^{19} \mathrm{~F} \mathrm{NMR}\left(\mathrm{CDCl}_{3}, 282 \mathrm{MHz}\right): \delta=-82.06\left(\mathrm{t}, J_{\mathrm{F}-\mathrm{F}}=2.3 \mathrm{~Hz}, \mathrm{CF}_{3}\right),-104.78(\mathrm{q}$, $\left.J_{\mathrm{F}-\mathrm{F}}=2.3 \mathrm{~Hz}, \mathrm{CF}_{2}\right)$.
(E)-Ethyl 4,4,5,5,5-Pentafluoro-2-(tributylgermyl)pent-2-enoate $[(E)-5 \alpha]$

(E)-5a was obtained as a mixture with $(Z)-\mathbf{5} \boldsymbol{\alpha}$ by following general procedure $\mathrm{A}$.

Yield: 84\%; colorless oil.

${ }^{1} \mathrm{H} \mathrm{NMR}\left(\mathrm{CDCl}_{3}, 300 \mathrm{MHz}\right): \delta=5.60\left(\mathrm{t}, J_{\mathrm{H}-\mathrm{F}}=13.3 \mathrm{~Hz}, 1 \mathrm{H}\right), 4.21(\mathrm{q}, J=$ $7.1 \mathrm{~Hz}, 2 \mathrm{H}), 1.38-1.25(\mathrm{~m}, 12 \mathrm{H}), 0.97-0.86(\mathrm{~m}, 18 \mathrm{H})$.

${ }^{13} \mathrm{C} \mathrm{NMR}\left(\mathrm{CDCl}_{3}, 75 \mathrm{MHz}\right): \delta=169.4,152.2\left(\mathrm{t}, J_{\mathrm{C}-\mathrm{F}}=4.7 \mathrm{~Hz}\right), 122.4(\mathrm{t}$, $\left.J_{\mathrm{C}-\mathrm{F}}=23.5 \mathrm{~Hz}\right), 111.6\left(\mathrm{tq}, J_{\mathrm{C}-\mathrm{F}}=252 / 38.5 \mathrm{~Hz}\right), 118.9\left(\mathrm{qt}, J_{\mathrm{C}-\mathrm{F}}=284.5 /\right.$ $37.1 \mathrm{~Hz}), 61.0,26.8$ (3C), $26.3(3 \mathrm{C}), 14.2,13.7$ (3C), $12.6(3 \mathrm{C})$.

${ }^{19} \mathrm{~F} \mathrm{NMR}\left(\mathrm{CDCl}_{3}, 282 \mathrm{MHz}\right): \delta=-84.91\left(\mathrm{t}, J_{\mathrm{F}-\mathrm{F}}=2.2 \mathrm{~Hz}, \mathrm{CF}_{3}\right),-113.95(\mathrm{q}$, $\left.J_{\mathrm{F}-\mathrm{F}}=2.2 \mathrm{~Hz}, \mathrm{CF}_{2}\right)$.

HRMS (ESI): $m / z$ [M $+\mathrm{H}]^{+}$calcd for $\mathrm{C}_{19} \mathrm{H}_{34} \mathrm{~F}_{5} \mathrm{GeO}_{2}$ : 463.16853; found: 463.16643.

(E)-Ethyl 4,4,5,5,5-Pentafluoro-3-(tributylgermyl)pent-2-enoate $[(E)-5 \beta]$

(E)-5 $\boldsymbol{\beta}$ was obtained as a mixture with the other three isomers by following general procedure $\mathrm{B}$.

${ }^{1} \mathrm{H} \mathrm{NMR}\left(\mathrm{CDCl}_{3}, 300 \mathrm{MHz}\right): \delta=6.31$ (bs, $\left.1 \mathrm{H}\right), 4.21(\mathrm{q}, J=7.1 \mathrm{~Hz}, 2 \mathrm{H})$, $1.38-1.25(\mathrm{~m}, 18 \mathrm{H}), 0.97-0.86(\mathrm{~m}, 12 \mathrm{H})$.

${ }^{19} \mathrm{~F} \mathrm{NMR}\left(\mathrm{CDCl}_{3}, 282 \mathrm{MHz}\right): \delta=-82.76\left(\mathrm{t}, J_{\mathrm{F}-\mathrm{F}}=1.8 \mathrm{~Hz}, \mathrm{CF}_{3}\right),-113.91(\mathrm{q}$, $J_{\mathrm{F}-\mathrm{F}}=1.8 \mathrm{~Hz}, \mathrm{CF}_{2}$ ).

(Z)-Ethyl 4,4,5,5,5-Pentafluoro-2-(tributylgermyl)pent-2-enoate $[(Z)-5 \alpha]$

$(Z)-5 \boldsymbol{\alpha}$ was obtained as a mixture with $(E)-\mathbf{5} \boldsymbol{\alpha}$ by following general procedure $\mathrm{A}$.

${ }^{1} \mathrm{H} \mathrm{NMR}\left(\mathrm{CDCl}_{3}, 300 \mathrm{MHz}\right): \delta=6.50\left(\mathrm{t}, J_{\mathrm{H}-\mathrm{F}}=14.8 \mathrm{~Hz}, 1 \mathrm{H}\right), 4.21(\mathrm{q}, J=$ $7.1 \mathrm{~Hz}, 2 \mathrm{H}), 1.38-1.25(\mathrm{~m}, 18 \mathrm{H}), 0.97-0.86(\mathrm{~m}, 12 \mathrm{H})$.

${ }^{19} \mathrm{~F} \mathrm{NMR}\left(\mathrm{CDCl}_{3}, 282 \mathrm{MHz}\right): \delta=-84.95\left(\mathrm{t}, J_{\mathrm{F}-\mathrm{F}}=2.5 \mathrm{~Hz}, \mathrm{CF}_{3}\right),-113.46(\mathrm{q}$, $\left.J_{\mathrm{F}-\mathrm{F}}=2.5 \mathrm{~Hz}, \mathrm{CF}_{2}\right)$.

(Z)-Ethyl 4,4,5,5,5-Pentafluoro-3-(tributylgermyl)pent-2-enoate $[(Z)-5 \beta]$

(Z)-5及 was obtained as a mixture with the other three isomers by following general procedure $B$.

${ }^{1} \mathrm{H} \mathrm{NMR}\left(\mathrm{CDCl}_{3}, 300 \mathrm{MHz}\right): \delta=6.84\left(\mathrm{t}, J_{\mathrm{H}-\mathrm{F}}=2.0 \mathrm{~Hz}, 1 \mathrm{H}\right), 4.21(\mathrm{q}, J=$ $7.1 \mathrm{~Hz}, 2 \mathrm{H}), 1.38-1.25(\mathrm{~m}, 18 \mathrm{H}), 0.97-0.86(\mathrm{~m}, 12 \mathrm{H})$.

${ }^{19} \mathrm{~F} \mathrm{NMR}\left(\mathrm{CDCl}_{3}, 282 \mathrm{MHz}\right): \delta=-82.29\left(\mathrm{t}, J_{\mathrm{F}-\mathrm{F}}=1.5 \mathrm{~Hz}, \mathrm{CF}_{3}\right),-105.48(\mathrm{q}$, $\left.J_{\mathrm{F}-\mathrm{F}}=1.5 \mathrm{~Hz}, \mathrm{CF}_{2}\right)$.

(E)-Methyl 4,4-Difluoro-4-phenyl-2-(triphenylgermyl)but-2enoate $[(E)-6 \alpha]$

(E)-6a was obtained as a mixture with the other three isomers by following general procedure $\mathrm{A}$.

${ }^{1} \mathrm{H}$ NMR $\left(\mathrm{CDCl}_{3}, 300 \mathrm{MHz}\right): \delta=7.61-7.25(\mathrm{~m}, 15 \mathrm{H}), 7.23-7.17(\mathrm{~m}$, $2 \mathrm{H}), 7.19-7.09(\mathrm{~m}, 2 \mathrm{H}), 7.08(\mathrm{t}, J=14.0 \mathrm{~Hz}, 1 \mathrm{H}), 6.88-6.86(\mathrm{~m}, 1 \mathrm{H})$, $3.04(\mathrm{~s}, 3 \mathrm{H})$.

${ }^{13} \mathrm{C} \mathrm{NMR}\left(\mathrm{CDCl}_{3}, 75 \mathrm{MHz}\right): \delta=165.8,152.7\left(\mathrm{t}, J_{\mathrm{C}-\mathrm{F}}=29.5 \mathrm{~Hz}\right), 142.2(\mathrm{t}$, $\left.J_{\mathrm{C}-\mathrm{F}}=29.8 \mathrm{~Hz}\right), 135.9\left(\mathrm{t}, J_{\mathrm{C}-\mathrm{F}}=2.4 \mathrm{~Hz}, 2 \mathrm{C}\right), 134.9(6 \mathrm{C}), 129.9\left(\mathrm{t}, J_{\mathrm{C}-\mathrm{F}}=\right.$ $1.3 \mathrm{~Hz}, 2 \mathrm{C}), 129.6,129.1$ (3C), 128.1 (3C), $127.9(6 \mathrm{C}), 125.7\left(\mathrm{t}, J_{\mathrm{C}-\mathrm{F}}=\right.$ $5.6 \mathrm{~Hz}, 1 \mathrm{C}), 122.23\left(\mathrm{t}, J_{\mathrm{C}-\mathrm{F}}=242.2 \mathrm{~Hz}, 1 \mathrm{C}, \mathrm{CF}_{2}\right), 51.4$.

${ }^{19} \mathrm{~F} \mathrm{NMR}\left(\mathrm{CDCl}_{3}, 282 \mathrm{MHz}\right): \delta=-85.31$.

(E)-Methyl 4,4-Difluoro-4-phenyl-3-(triphenylgermyl)but-2enoate $[(E)-6 \beta]$

(E)-6 $\boldsymbol{\beta}$ was obtained as a mixture with the other three isomers by following general procedure $A$. 
${ }^{1} \mathrm{H}$ NMR $\left(\mathrm{CDCl}_{3}, 300 \mathrm{MHz}\right): \delta=7.61-7.25(\mathrm{~m}, 15 \mathrm{H}), 7.23-7.17(\mathrm{~m}$, $2 \mathrm{H}$ ), (m, $2 \mathrm{H}), 7.19-7.09$ ( $\mathrm{m}, 2 \mathrm{H}), 6.40$ (t, $J=1.7 \mathrm{~Hz}, 1 \mathrm{H}), 6.88-6.86$ (m, $1 \mathrm{H}), 3.59$ (s, $3 \mathrm{H})$.

${ }^{19} \mathrm{~F} \mathrm{NMR}\left(\mathrm{CDCl}_{3}, 282 \mathrm{MHz}\right): \delta=-91.30$.

(Z)-Methyl 4,4-Difluoro-4-phenyl-2-(triphenylgermyl)but-2enoate $[(Z)-6 \alpha]$

(Z)-6a was obtained as a mixture with the other three isomers by following general procedure $\mathrm{A}$.

${ }^{1} \mathrm{H}$ NMR $\left(\mathrm{CDCl}_{3}, 300 \mathrm{MHz}\right): \delta=7.61-7.25(\mathrm{~m}, 15 \mathrm{H}), 7.23-7.17(\mathrm{~m}$, $2 \mathrm{H}),(\mathrm{m}, 2 \mathrm{H}), 7.19-7.09(\mathrm{~m}, 2 \mathrm{H}), 6.05(\mathrm{t}, J=12.1 \mathrm{~Hz}, 1 \mathrm{H}), 6.88-6.86$ (m, $1 \mathrm{H}), 3.46(\mathrm{~s}, 3 \mathrm{H})$.

${ }^{19} \mathrm{~F} \mathrm{NMR}\left(\mathrm{CDCl}_{3}, 282 \mathrm{MHz}\right): \delta=-78.11$.

\section{(Z)-Methyl 4,4-Difluoro-4-phenyl-3-(triphenylgermyl)but-2- enoate $[(Z)-6 \beta]$}

(Z)-6/ was obtained as a mixture with the other three isomers by following general procedure $\mathrm{A}$.

${ }^{1} \mathrm{H}$ NMR $\left(\mathrm{CDCl}_{3}, 300 \mathrm{MHz}\right): \delta=7.61-7.25(\mathrm{~m}, 15 \mathrm{H}), 7.23-7.17(\mathrm{~m}$, $2 \mathrm{H}),(\mathrm{m}, 2 \mathrm{H}), 7.19-7.09(\mathrm{~m}, 2 \mathrm{H}), 7.13(\mathrm{t}, J=2.7 \mathrm{~Hz}, 1 \mathrm{H}), 6.88-6.86$ (m, $1 \mathrm{H}), 3.20(\mathrm{~s}, 3 \mathrm{H})$.

${ }^{19} \mathrm{~F} \mathrm{NMR}\left(\mathrm{CDCl}_{3}, 282 \mathrm{MHz}\right): \delta=-90.26$.

\section{Acknowledgment}

We would like to thank the Association of Specialization and Scientific Orientation (Lebanon) and Lebanese University for their support. We thank also the Département d'analyses Chimiques et Médicales (Tours, France) for chemical analyses.

\section{Supporting Information}

Supporting information for this article is available online at https://doi.org/10.1055/s-0037-1611666.

\section{References}

(1) (a) Hunter, L. Beilstein J. Org. Chem. 2010, 6, 1. (b) Biomedicinal Aspects of Fluorine Chemistry; Filler, R.; Kobayashi, Y., Ed.; Kodansha Ltd: Tokyo, 1982. (c) Ojima, I. Fluorine in Medicinal Chemistry and Chemical Biology; Wiley-Blackwell: UK, 2009.

(2) Dinoiu, V. Rev. Roum. Chim. 2006, 51, 1141.

(3) The Practice of Medicinal Chemistry; Wermuth, C., Ed.; Academic Press: London, 1996, 203.

(4) (a) Smart, B. E. Chem. Rev. 1996, 96, 1555. (b) Banks, R. E.; Smart, B. E.; Tatlow, J. C. Organofluorine Chemistry: Principle and Commercial Application; Plenum Press: New York, 1994. (c) van Niel, M. B.; Collins, I.; Beer, M. S.; Broughton, H. B.; Cheng, S. K. F.; Goodacre, S. C.; Heald, A.; Locker, K. L.; MacLeod, A. M.; Morrison, D.; Moyes, C. R.; O'Connor, D.; Pike, A.; Rowley, M.; Russell, M. G. N.; Sohal, B.; Stanton, J. A.; Thomas, S.; Verrier, H.; Watt, A. P.; Castro, J. L. J. Med. Chem. 1999, 42, 2087. (d) Arnone, A.; Bravo, P.; Donadelli, A.; Resnati, G. Tetrahedron 1996, 52, 131.

(5) (a) Zhou, P.; Qian, L.; Kozopas, K. M.; Craig, R. W. Blood 1997, 89, 630. (b) Zhou, Q.; Salvesen, G. S. J. Biol. Chem. 1997, 324, 361. (c) Zhou, Q.; Snipas, S.; Orth, K.; Muzio, M.; Dixit, V. M.; Salvesen, G. S. J. Biol. Chem. 1997, 272, 7797.

(6) (a) Thompson, C. B. Science 1995, 267, 1456. (b) Altmann, K. H.; Pfeiffer, B.; Arseniyadis, S.; Pratt, B. A.; Nicolaou, K. C. ChemMedChem 2007, 2, 396.
(7) Kobayashi, T.; Eda, T.; Tamura, O.; Ishibashi, H. J. Org. Chem. 2002, 67, 3156.

(8) Besset, T.; Poisson, T.; Pannecoucke, X. Chem. Eur. J. 2014, 20, 16830.

(9) (a) Akiyama, T. Main Group Metals in Organic Synthesis; Wiley: Weinheim, 2004, 593. (b) Spivey, A. C.; Gripton, C. J. G.; Hannah, J. P. Org. Synth. 2004, 1, 211.

(10) Bowman, W. R.; Krintel, S. L.; Schilling, M. B. Org. Biomol. Chem. 2004, 2, 585.

(11) Wolfsberger, W. J. Prakt. Chem. 1992, 334, 453.

(12) (a) Esteruelas, M. A.; Martín, M.; Oro, L. A. Organometallics 1999, 18, 2267. (b) Kinoshita, H.; Nakamura, T.; Kakiya, H.; Shinokubo, H.; Matsubara, S.; Oshima, K. Org. Lett. 2001, 3, 2521. (c) Faller, J. W.; Kultyshev, R. G. Organometallics 2003, 22, 199. (d) Matsuda, T.; Kadowaki, S.; Yamaguchi, Y.; Murakami, M. Org. Lett. 2010, 12, 1056. (e) Ichinose, Y.; Nozaki, K.; Wakamatsu, K.; Oshima, K.; Utimoto, K. Tetrahedron Lett. 1987, 28, 3709. (f) Corriu, R. J. P.; Moreau, J. J. E. J. Chem. Soc. D 1971, 812. (g) Wada, F.; Abe, S.; Yonemaru, N.; Kikukawa, K.; Matsuda, T. Bull. Chem. Soc. Jpn. 1991, 64, 1701. (h) Lukevics, E.; Barabanov, D. I.; Ignatovich, L. M. Appl. Organomet. Chem. 1991, 5, 379.

(13) Prié, G.; Thibonnet, J.; Abarbri, M.; Duchêne, A.; Parrain, J.-L. Synlett 1998, 839.

(14) Carcenac, Y.; Zine, K.; Kizirian, J. C.; Thibonnet, J.; Duchêne, A.; Parrain, J.-L.; Abarbri, M. Adv. Synth. Catal. 2010, 352, 949.

(15) (a) Thibonnet, J.; Duchêne, A.; Parrain, J.-L.; Abarbri, M. J. Org. Chem. 2004, 69, 4262. (b) David-Quillot, F.; Thibonnet, J.; Marsacq, D.; Abarbri, M.; Duchêne, A. Tetrahedron Lett. 2000, 41, 9981.

(16) Palmas, P.; Thibonnet, J.; Parrain, J.-L.; Abarbri, M.; David-Quillot, F.; Duchêne, A. Magn. Reson. Chem. 2002, 40, 537.

(17) Besset, T.; Poisson, T.; Pannecoucke, X. Chem. Eur. J. 2014, 20 , 16830.

(18) Konno, T. Synlett 2014, 25, 1350.

(19) Jacquet, J.; Blanchard, S.; Derat, E.; Murr, M. D.-E.; Fensterbank, L. Chem. Sci. 2016, 7, 2030.

(20) Schweizer, S.; Tresse, C.; Bisseret, P.; Lalevée, J.; Evano, G.; Blanchard, N. Org. Lett. 2015, 17, 1794.

(21) Minisci, F.; Citterio, A.; Giordano, C. Acc. Chem. Res. 1983, 16, 27.

(22) (a) Nozaki, K.; Oshima, K.; Uchimoto, K. J. Am. Chem. Soc. 1987, 109, 2547. (b) Nozaki, K.; Oshima, K.; Utimoto, K. Tetrahedron 1989, 45, 923. (c) Satoh, S.; Sodeoka, M.; Sasai, H.; Shibasaki, M. J. Org. Chem. 1991, 56, 2278. (d) Lowinger, T. B.; Weiler, L. J. Org. Chem. 1992, 57, 6099. (e) Guindon, Y.; Jung, G.; Guérin, B.; Ogilvie, W. W. Synlett 1998, 213. (f) Shuto, S.; Kanazaki, M.; Ichikawa, S.; Matsuda, A.J. Org. Chem. 1997, 62, 5676. (g) Sibi, M. P.; Shay, J.; Ji, J. Tetrahedron Lett. 1997, 38, 5955. (h) Miyabe, H.; Shibata, R.; Ushiro, C.; Naito, T. Tetrahedron Lett. 1998, 39, 631. (i) Devin, P.; Fensterbank, L.; Malacria, M. Tetrahedron Lett. 1998, 39, 833.

(23) Schwier, T.; Gevorgyan, V. Org. Lett. 2005, 7, 5191.

(24) For Lewis acid catalyzed hydrosilylation, see: (a) Kato, N.; Tamura, Y.; Kashiwabara, T.; Sanji, T.; Tanaka, M. Organometallics 2010, 29, 5274. (b) Liu, Y.; Yamazaki, S.; Yamabe, S. J. Org. Chem. 2005, 70, 556; For Lewis acid catalyzed hydrostannylation, see. (c) Asao, N.; Liu, J.-X.; Sudoh, T.; Yamamoto, Y. J. Org. Chem. 1996, 62, 4568. (d) Asao, N.; Liu, J.-X.; Sudoh, T.; Yamamoto, Y. J. Chem. Soc., Chem. Commun. 1995, 2405.

(25) Khalaf, A.; Grée, D.; Abdallah, H.; Jaber, N.; Hachem, A.; Grée, R. Tetrahedron 2011, 67, 3881.

(26) Reed, A. E.; Weinstock, R. B.; Weinhold, F. J. Chem. Phys. 1998, 83,735 . 